\title{
Application of combustible wastes for the alternative fuels production
}

\author{
Marek Kułażyński, Andrzej Surma, Jerzy Walendziewski \\ Wroctaw University of Technology, Faculty of Chemistry, Department of Fuels Chemistry and Technology, \\ ul. Gdańska 7/9, 50-344 Wrocław, Poland, e-mail: jerzy.walendziewski@pwrwroc.pl
}

The information on the quantity of various types of combustible wastes registered in the Lower Silesia Marshal Office over the 2003 - 2005 years (waste codes - 02, 03, 04, 07, 12, 15, 16, 17, 19 and 20) was collected and then the quantities of individual wastes from different sources were summarized depending on the waste sort i.e. waste paper (cellulose), plastics, timber, textiles and rubber. The physiochemical properties and the chemical composition of the impurities in the selected waste sorts were determined and discussed while taking into account their usefulness and the necessary treatment operations for the alternative fuels production.

Keywords: industrial wastes, municipal wastes, alternative fuels, calorific value, waste codes, combustible materials, combustion.

Presented at VII Conference Wasteless Technologies and Waste Management in Chemical Industry and Agriculture, Międzyzdroje, 12 - 15 June, 2007.

\section{INTRODUCTION}

Energy recovery from waste materials can be realized using two different methods. In the simplest way one considers only the incineration of the mixed municipal or industrial flammable wastes. Energy recovery can be also realized by fuel production, refuse-derived fuels (RDF) or packaging-derived fuels $(\mathrm{PDF})^{\mathbf{1 - 3}}$. They can be mechanically separated from municipal wastes (RDF) or sourceseparated (PDF). Co-combustion of RDF and PDF (alternative fuels) with fossil fuels can partially substitute fossil fuels and in this way contribute to resource conservation.

The production of alternative fuels can be realized using various operations, e.g. shredding, separation, sieving, pelletizing, densification and others. The obtained products should, however, fulfill a few basic requirements:

- according to the law they can be submitted to thermal recovery,

- they should be suitably milled and mixed,

- they should have the required heating value,

- they should have the required chemical composition (admissible impurities content).

Alternative fuels (secondary or supplementary fuels) can be solid or liquid wastes (municipal or industrial), eg. waste rubbers, scrap tires, plastics, paints, timber, animal and vegetable refuses. The utilization of wastes as alternative fuels also results in environment advantages, such as the limitation of waste and emissions. As a result of the technological process the obtained alternative fuels looks like grey granules (pellets, briquettes), which can be used in industrial or energetic boilers, co-combusted with coal (brown or hard) or instead of coal. In this case one can obtain the so-called densified fuels, it means RDF in the form of the grain. The term "densifying” was accepted as a description of the forming operation: pelletizing, briquetting or another method of RDF compressing into grains, which can be burned on a grate. The application of the forming operation makes it possible not only to obtain RDF in the grain form but also to increase the density of the fluffy fuel considerably and improve the transport and the usable properties. The calorific value of the most typical combustible wastes is presented in Table 1.
Table 1. The calorific values of the wastes used as the components of alternative fuels

\begin{tabular}{|l|c|}
\hline Name of alternative fuel & $\begin{array}{c}\text { Calorific value } \\
{[\mathrm{MJ} / \mathrm{kg}]}\end{array}$ \\
\hline Waste tires & 29,2 \\
\hline Waste plastics & $40-46$ \\
\hline Waste paper & ca. 11 \\
\hline Waste timber & ca. 18 \\
\hline Waste solvents & 25 \\
\hline Waste rubbers & 30 \\
\hline Waste oils & 40 \\
\hline Municipal waste & $7.0-10.0$ \\
\hline Water -liquid hydrocarbons emulsions & $12-17$ \\
\hline $\begin{array}{l}\text { Post refining tars, waste beaching } \\
\text { adsorbents }\end{array}$ & 21 \\
\hline Chlorinated hydrocarbons & 27 \\
\hline Bituminous shale & $12-18$ \\
\hline Coal muds & $12-18$ \\
\hline $\begin{array}{l}\text { Water emulsion from neutralized post } \\
\text { refining tars }\end{array}$ & 16,7 \\
\hline $\begin{array}{l}\text { Oiled suspension from beaching adsorbents } \\
\text { and waste greases }\end{array}$ & 27,2 \\
\hline $\begin{array}{l}\text { Waste oils and their mixture with waste solid } \\
\text { greases }\end{array}$ & 33,5 \\
\hline
\end{tabular}

In Polish nomenclature such kind of the milled solid fuels is named as PAS-r. As a rule the final products are grained materials with an average diameter ca $70 \mathrm{~mm}$ and the calorific value $18-23 \mathrm{MJ} / \mathrm{kg}$. In many countries the calorific value is the base alternative fuel parameter, at least ca $4 \mathrm{kcal} / \mathrm{kg}$ and the determined content of the impurities, e.g. the data given in Table $2^{2}$.

Table 2. An admissible content of the impurities in RDF in Italy $^{2}$

\begin{tabular}{|l|c|}
\hline Requirements & Values \\
\hline Min. calorific value, kcal/kg & 3584 \\
Max. wetness, wt \% & 25 \\
Max. ash content in dry fuel, wt \% & 20 \\
Max. chlorine, content, wt \% & 0,9 \\
Max. sulphur content, wt \% & 0,6 \\
Max. Pb content in dry fuel, ppm & 200 \\
Max. Cr content in dry fuel, ppm & 100 \\
Max. Cu content in dry fuel, ppm & 300 \\
Max. Mn content in dry fuel, ppm & 400 \\
Max. Ni content in dry fuel, ppm & 40 \\
Max. As content in dry fuel, ppm & 9 \\
Max. Cd + Hg content, ppm & 7 \\
\hline
\end{tabular}


The other types of alternative fuels are:

- PAS-i - impregnated solid fuels, i.e. the fuels produced by mixing the solid and liquid combustible materials. So the semi-dry fuels are produced by the impregnation of solid porous materials (timber dust, textiles) with waste lubrication and heavy oils, waste paints, lacquers and so on. The final product is the granulated fuel with the calorific value $8-11 \mathrm{MJ} / \mathrm{kg}$.

- Liquid fuels are produced by mixing the liquid combustible wastes. They are the substitutes of heavy fuel oils and are the result of the purification, mixing and the selection of components according to the final user requirements. This type of alternative fuels is characterized by a high calorific value, $30-36 \mathrm{MJ} / \mathrm{kg}$.

According to the Polish law ${ }^{4-6}$ the combustion or the co-combustion of alternative fuels (RDF) can be realized only in the special energetic plants, equipped with the required indicating and controlling devices. The basic law requirements connected with waste combustion processes comprise:

-requirements for the standing of emission standards,

- requirements determining the needful process parameters,

- requirements describing the measurements range, the process monitoring parameters and of the hazardous emission level.

For instance, according to the above Instruction the following parameters have to be continuously determined in the course of the co-combustion process:

- flue gases temperature,

- oxygen content in flue gases streams,

- flue gases temperature.

The total incineration of the waste materials in fuels has to be assured by strong requirement to control the combustion temperature:

- above $1100^{\circ} \mathrm{C}$ for the wastes containing more than 1 wt $\%$ chlorine,

- above $850^{\circ} \mathrm{C}$ for the wastes containing less than $1 \mathrm{wt}$ $\%$ chlorine

and the content of organic carbon in ash lower than $3 \mathrm{wt} \%$.

The co-combustion plants comprise the apparatuses and devices used for the realization of thermal waste conversion including the purification of flue gases, the monitoring and control of the process, installations used for acceptance, the preliminary treatment and the storage wastes for thermal processing as well as the installments for the storage and conversion of materials obtained as a result of the incineration and purification of the flue gases.

\section{EXPERIMENTAL}

In this paper we are presenting a quantity of various types of wastes registered in the Lower Silesia Marshal Office over the 2003, 2004 and 2005 years, according to the waste codes - 02, 03, 04, 07, 12, 15, 16, 17, 19 and 20:

03. - Wastes from the processing of timber and the production of furniture, cellulose and cardboard,

04. - Wastes from leather, furriery and textiles industries,

07. - Wastes from the production, handling and application of organic chemistry materials,

12. - Wastes form the shaping, physical and mechanical processing of metals and plastics surface,
15. - Package wastes, adsorbents, textiles and filtrations materials and protective clothes,

16. - Wastes not included in other groups - waste or unsuitable for exploitation vehicles, waste tires,

17. - Waste from the construction, reparations and dismantling of buildings and roads infrastructure (including the soil from polluted areas),

19. - Wastes from the plants and devices used for the utilization of wastes from a sewage purification plant and conditioning of water for drinking and industrial purposes.

In the next step the wastes shown under individual codes are divided, with groups, sub-groups and sorts of combustible materials taken into account. The quantity of all sorts of combustible waste materials included in different material codes, i.e. paper (cellulose), plastics, timber, textiles and rubbers were summarized and are presented in Table 3.

Table 3. The total content of combustible wastes as registered by the Lower Silesia Marshall Office in the 2003, 2004 and 2005 years (according to the summarized sort of wastes)

\begin{tabular}{|l|l|r|r|r|}
\hline No & $\begin{array}{l}\text { Sort of combustible } \\
\text { waste }\end{array}$ & 2003 & 2004 & 2005 \\
\hline 1 & Plastics & 7852,70 & 12307,20 & 18951,60 \\
\hline 2 & Textiles & 2264,10 & 2375,90 & 1280,60 \\
\hline 3 & Rubber & 3574,00 & 3845,80 & 3431,30 \\
\hline 4 & Timber & 68534,80 & 98239,40 & 36445,20 \\
\hline 5 & $\begin{array}{l}\text { Waste paper and } \\
\text { cellulose }\end{array}$ & 15906,00 & 25457,00 & 91876,20 \\
\hline 6 & Mixed wastes & 7630,50 & 18066,70 & 23976,70 \\
\hline Total & & 105762,10 & 160292,00 & 175961,60 \\
\hline
\end{tabular}

Table 3 presents the quantity of combustible wastes registered by the Lower Silesia Marshall Office in 2003, 2004 and 2005, respectively. One can see that the quantity of the registered wastes is strongly increasing, especially in the case waste plastics and cellulose. Furthermore, it is worthy to notice that a presumably large part of theses wastes was not registered and was earlier submitted to incineration or land filling.

\section{Alternative fuels production line}

The alternative fuels production line should comprise several operations aimed at separating the combustible and mineral components and the treatment of the combustible matters. The goal of the production line is obtaining alternative fuels of predetermined properties and the main unit operations are screening, shredding, milling (size reduction), classification, sometimes drying and densification. The proper selection of the process devices along the production line determines the quantity and quality of the final product. The most important operation in the line is screening with the use of screens, hand sorting, magnetic selection in order to remove the hard to shred components (e.g. pieces of metals, stones) and to avoid an excessive wear of the device in the plant, mainly the mills. In the next stage the selected combustible wastes should be shredded or milled depending the on the wastes size. Because of a possible presence of metal scraps the milling operation is preceded by magnetic separation or another similar operation (e.g. air classification). As a rule the application of crumbling devices, shredders and mills is necessary, since the mill makes further size reduc- 
Table 4. The alternative fuel line production cost data ${ }^{2}$

\begin{tabular}{|l|c|c|c|c|c|}
\hline Equipment name & $\begin{array}{c}\text { Capacity } \\
(\mathrm{t} / \mathrm{h})\end{array}$ & Power $(\mathrm{kW})$ & Cost, $(\mathrm{k} €)$ & $\begin{array}{c}\text { Amortization } \\
(€ / \mathrm{h})\end{array}$ & Operating cost $€ / \mathrm{h}$ \\
\hline Trommel screen & 15 & 20 & ca 103 & 2.36 & 2.960 \\
Shredder & 15 & 50 & ca 129 & 3.556 & 3,45 \\
Hammer mill & 6 & 300 & ca 155 & 0.95 & 2.62 \\
Air classifier & 5 & 12 & ca 41 & 0.69 \\
Dryer & 6 & 140 & ca 310 & 15 & 10.12 \\
Belt conveyor & - & 6 & 15 & 1.14 & 0.43 \\
Eddy current separator & 15 & 5.2 & 207 & 4.73 & 0.48 \\
Densifier & 6 & 50 & 207 & 4.73 & 3,62 \\
Pelletizer & 4 & - & - & - & 3.62 \\
Hand sorting & - & & & & 23.65 \\
\hline
\end{tabular}

tion carried out by shredder, possible ${ }^{2}$. The application of the shredder is also necessary because without this device the mill throughput is reduced and its energy consumption increases. If a parallel composting line is planned, the inorganic component (glass, metals) should be separated in order to prevent compost polluting. In this case it is necessary to start the production line with screen as well as hand sorting-magnetic eddy current-hand separation and to prevent glass and metal shredding and mixing with compost. Hand sorting must always precede the shredding operation.

The economic design of an alternative production line is a very hard task because:

- it is difficult to foresee the waste composition changing over the time and

- the process devices are adopted from other industry branches with various capacity and their selection is difficult for the realization when their efficiency production is considered.

Improper devices selection will result in the reduced throughput and/or the lower quality of the final product.

The total operating costs are mainly influenced by hand sorting (labor costs), by hammer mills (serious problem with size reduction) and dryer operation costs (energy consumption) (Table 4). Hand sorting (human participation) also poses problems because of hygiene and safety requirements. However, hand sorting is sometimes necessary.

The bulk density of combustible wastes is low (even below $200 \mathrm{~kg} / \mathrm{m}^{3}$ ) and therefore the densification of palletizing is necessary. Application of these operations makes it possible to increase the density to that higher than $400 \mathrm{~kg} / \mathrm{m}^{3}$ and easy for transportation, dosing and mixing with coal. As a rule, the better segregation means the higher calorific value of the obtained alternative fuel and lower fuel capacity. The capacity of the alternative fuel production plants should be in the range $25-200 t /$ h. Greater plants can be uneconomical from the logistic and transportation point of view.

In our experiment mainly the industrial wastes (rubber, textiles, upholstery, waste paper and wood (furniture) were applied. The selected wastes were hand sorted, shredded and milled and next mechanically mixed with hard coal, $16 \%$ combustible wastes and $84 \%$ hard coal.

\section{The applied analytic methods}

Flammable wastes properties

Ash content determination: according to the Polish Standard PN-80/G-4512, by the incineration of the $10 \mathrm{~g}$ sample and calcination at the temperature of $815^{\circ} \mathrm{C}$.
Total sulphur content determination: according to the Polish Standard PN-80/G-4514/02, by the incineration of the $0.5 \mathrm{~g}$ sample in oxygen stream $\left(1250^{\circ} \mathrm{C}\right), \mathrm{SO}_{2}$ absorbing in $\mathrm{H}_{2} \mathrm{O}_{2}$ solution and alkali metric determination of the $\mathrm{H}_{2} \mathrm{SO}_{4}$.

The calorific and heating value: according to the Polish Standard PN-80/G-4513, by the incineration of the $0.8-$ $1.0 \mathrm{~g}$ sample in oxygen atmosphere, $0.3 \mathrm{MPa}$. (calorimetric method).

Ash composition (mineral components)

- By a selective solution of ash samples in acid solutions or a pyrolysis with sodium carbonate and the determination of metal components content in water solution using the ASA method (Perkin Elmer 503).

$-\mathrm{SiO}_{2}$ and sulphate ion contents were determined by the gravimetric method.

- Chlorides ions content were determined by the titration method with the KCNS solution being used.

\section{Physicochemical properties of combustible wastes}

The base physicochemical properties of the main combustible wastes are shown in Table 5 .

Plastics, scrap tires and rubber presented the highest calorific value, $(35-40 \mathrm{MJ} / \mathrm{kg})$ while waste paper contained the highest content of water and was a little worse fuel. The calorific value of waste paper and waste wood (milled furniture) as well as the energetic willow was similar and attained the value of $16-18 \mathrm{MJ} / \mathrm{kg}$. An appropriate selection of the alternative fuel component (high and low calorific value) gave alternative fuels (code 19-12-10) with the calorific value similar to that of hard coal (ca $22 \mathrm{MJ} / \mathrm{kg}$ ), low ash content (ca 6 wt \%) and a considerably low sulphur content $(0.2 \mathrm{wt} \%)$. This is due to the fact that only scrap tires contained an appreciable quantity of sulphur. Sulphur content in other wastes was lower than $0.5 \mathrm{wt} \%$. The studied combustible wastes contained a relatively low quantity of heavy metals. Only waste scrap tires and waste paper contained larger $\mathrm{Zn}$ quantity (Table 6).

A quantitative ash analysis showed a heightened chlorine concentration in waste scrap tires and waste paper. However, the main components of the analyzed ashes were quite neutral constituents, i.e. silica, alumina as well as iron and calcium oxides.

Depending on the origin waste combustible materials contain various quantities of heavy metals and chlorine (mainly from polyvinyl chloride derivatives). In the grate boilers the combustion temperature attains more than 1000 ${ }^{\circ} \mathrm{C}$ while in dust boilers $1300-1600^{\circ} \mathrm{C}$. According to Klein et $\mathrm{al}^{7}$ metals in combustible wastes can be divided into three groups. The first group includes $\mathrm{Al}, \mathrm{Ba}, \mathrm{Ca}, \mathrm{Co}$, 
Table 5. The physicochemical properties of the combustible wastes

\begin{tabular}{|c|c|c|c|c|c|c|}
\hline \multicolumn{2}{|r|}{ Type of waste } & \multirow{2}{*}{$\begin{array}{c}\text { Wetness } \\
\mathrm{W}_{t}^{r} \% \\
0.3\end{array}$} & \multirow{2}{*}{$\begin{array}{c}\text { Ash content } \\
A^{r} \% \\
0.8 \\
\end{array}$} & \multirow{2}{*}{$\begin{array}{c}\begin{array}{c}\text { Sulphur } \\
\text { content }\end{array} \\
\mathrm{S}_{t}^{r} \% \\
0.250 \\
\end{array}$} & \multirow{2}{*}{$\begin{array}{c}\begin{array}{c}\text { Combustion } \\
\text { heat }\end{array} \\
\mathrm{Q}_{s}^{r}, \mathrm{MJ} / \mathrm{kg} \\
42.3\end{array}$} & \multirow{2}{*}{$\begin{array}{c}\begin{array}{c}\text { Calorific } \\
\text { value }\end{array} \\
\mathrm{Q}_{i}^{r}, \mathrm{MJ} / \mathrm{kg} \\
41.4\end{array}$} \\
\hline Plastics & Package plastics & & & & & \\
\hline \multirow{3}{*}{ Textiles } & Car upholstery (pressed) & 8.0 & 0.4 & 2.1 & 24.3 & 22.3 \\
\hline & Waste textiles & 1.1 & 2.0 & $<0.1$ & 19.2 & 18.5 \\
\hline & Pieces of industrial upholstery & 5.9 & 6.5 & 0.5 & 18.4 & 17.4 \\
\hline \multirow[b]{2}{*}{ Rubber } & Car rubber wastes & 0.8 & 6.7 & 0.1 & 39.4 & 38.3 \\
\hline & Scrap tires & 0.5 & 4.6 & 3.2 & 38.2 & 37.4 \\
\hline \multirow[b]{2}{*}{ Wood } & Energetic willow & 6.8 & 2.1 & 0.2 & 17.1 & 16.5 \\
\hline & Furniture wastes & 4.5 & 1.3 & 0.2 & 18.5 & 18.1 \\
\hline Cellulose & Package waste paper & 6.5 & 14.6 & 0.3 & 16.4 & 15.2 \\
\hline \multirow{2}{*}{ Mixed wastes } & Mixed waste, (code 19-12-10) & 4.6 & 6.25 & 0.2 & 23.4 & 22.5 \\
\hline & Pellet (code 19-12-10) & 3.4 & 3.24 & 0.1 & 22.7 & 21.9 \\
\hline
\end{tabular}

Explanation: 19-12-10 code: mixed combustible wastes processed to alternative fuel and Pellet (code 19-12-10) after palletizing.

$\mathrm{W}_{t}^{r}$ - the total wetness of the delivered waste, $\mathrm{A}^{r}$ - ash content in thę delivered waste, $\mathrm{S}-$ sulphur content in the delivered waste

$\mathrm{Q}_{i}^{r}$ - the calorific value of the delivered waste, $\mathbf{Q}_{s}^{r}$ - the heat of combustion.

The delivered sample - the sample of the waste without additional treatment.

Table 6. Metals content in mineral residues (ash) obtained after the combustion of the selected combustible wastes

\begin{tabular}{|c|c|c|c|c|c|c|c|c|c|c|c|c|c|c|c|c|}
\hline \multirow{2}{*}{$\begin{array}{l}\text { Waste } \\
\text { name }\end{array}$} & \multirow{2}{*}{\begin{tabular}{|c|}
$\begin{array}{c}\text { Pyrolysis } \\
\text { losses, } \\
\text { wt \%. }\end{array}$ \\
\end{tabular}} & \multicolumn{15}{|c|}{ Mineral components content in ash, wt \% } \\
\hline & & $\mathrm{Fe}_{2} \mathrm{O}_{3}$ & $\mathrm{~K}_{2} \mathrm{O}$ & $\mathrm{Al}_{2} \mathrm{O}_{3}$ & $\mathrm{CaO}$ & $\mathrm{SiO}_{2}$ & $\mathrm{SO}_{3}$ & $\mathrm{P}_{2} \mathrm{O}_{5}$ & $\mathrm{Ba} 0$ & $\mathrm{~Pb}$ & $\mathrm{Cr}$ & $\mathrm{Cu}$ & $\mathrm{Ni}$ & $\mathrm{V}$ & $\mathrm{Zn}$ & $\mathrm{Cl}$, \\
\hline Rubber & 93.30 & 2.96 & 1.67 & 6.08 & 12.8 & 46.61 & 5.80 & 0.30 & 0.39 & 0.06 & 0.02 & 0.05 & 0.039 & 0.003 & 22.08 & 17.3 \\
\hline Textiles & 97.56 & 4.39 & 1.62 & 13.32 & 14.8 & 43.53 & 5.47 & 0.55 & 1.06 & 0.05 & 0.02 & 0.92 & 0.036 & 0.006 & 0.93 & 0.25 \\
\hline $\begin{array}{l}\text { Waste } \\
\text { paper }\end{array}$ & 88.06 & 5.20 & 0.29 & 8.01 & 3.15 & 24.97 & 1.85 & 0.50 & 0.09 & 0.04 & 0.02 & 0.04 & 0.05 & 0.006 & 0.27 & 14.7 \\
\hline 19.12 .10 & 88.05 & 4.15 & 1.22 & 8.18 & 11.2 & 38.47 & 4.32 & 0.46 & 0.45 & 0.04 & 0.05 & 0.04 & 0.04 & 0.002 & 0.74 & 10.2 \\
\hline Hard coal & 80.49 & 10.66 & 2.43 & 24.93 & 18.9 & 31.80 & 10.2 & 0.80 & 0.72 & 0.02 & 0.02 & 0.05 & 0.025 & 0.028 & 0.12 & 0.2 \\
\hline
\end{tabular}

$\mathrm{Fe}, \mathrm{K}, \mathrm{La}, \mathrm{Mg}, \mathrm{Mn}, \mathrm{Si}$, Ta, Ti Te that are collected in ashes. The elements of the third group $\mathrm{Hg}$ and $\mathrm{Cl}$ are in the gaseous phase and are transported with flue gases. According to $\mathrm{Greenberg}^{8}$ the presence of $\mathrm{HCl}$ in flue gases exerts a large influence on elements volatility. The heightened content of chlorine makes generating of relative volatile metals chlorides (mainly $\mathrm{Hg}, \mathrm{Pb}, \mathrm{Zn}, \mathrm{Ni}, \mathrm{Cd}$ ) possible. However, the co-combustion up to $25 \%$ of alternative fuels with coal should not result in an increase of heavy metals emission in flue gases.

The combustion temperature in fluid bed boilers (750 $-900^{\circ} \mathrm{C}$ ), lower than in other boilers, should theoretically decrease metals emission but a higher fuel retention time can increase metals compound emission. According to the thermodynamic calculation $\mathrm{Cd}, \mathrm{Hg}$ and $\mathrm{Sn}$ can vaporize to a large extent ${ }^{9}$. On the other hand, the application of Ca compounds as de-sulphurizing compound results in a higher dust emission and as a result a heightened emission of many metals ( $\mathrm{As}, \mathrm{Co}, \mathrm{Cr}, \mathrm{Cu}, \mathrm{Ni}$ and $\mathrm{Pb}$ ) adsorbed at dust particles.

The main problem of co-combustion of waste with hard coal is a considerable high difference in bulk density. Especially the low density $\left(120-150 \mathrm{~kg} / \mathrm{m}^{3}\right)$ was found for waste paper, textiles and waste upholstery as well as energetic plants and waste wood. A relatively high density was presented only by scrap tires and rubber wastes. Despite accurate milling such combustible wastes gave light, fluffy material. Therefore, it was difficult to prepare stable alternative fuel in the mixture with hard coal. During the transport to the boiler with belt conveyors a distinct separation of the materials was observed; light combustible material was quite separated from coal and accumulated as the upper layer in the coal-waste mixture. This phenomenon results in an uneven fuel distribution over the grate and problems with the excessively fast combustion of the fluffy wastes in comparison to the hard coal and resulting in the grate failure.

Therefore, it is necessary to work up an efficient method of the densification and granulation of wastes. It is quite easy to form them in briquettes or pellets, which can be easily combusted as individual fuels. Energetic co-combustion of wastes with hard coal (e.g. in fluidized bed boilers) needs, however, granulated wastes of small grain, i.e. only densification.

\section{The energetic value of the combustible wastes}

The annual generation of combustible wastes in the Lower Silesia area in 2005 attained almost 176000 tons (Table 3). On the base of these data, the calorific value and the weight of combustible wastes one can calculate the weight of the fossil fuels, e.g. hard coal, which can be replaced in the energy generation process by waste materials. Table 7 present the results of the calculation of the hard coal weight, the replacement of which by the registered combustible waste is possible, taking into account the weight of the collected waste and the ratio of the approx. calorific value of individual wastes to the calorific value of hard coal (24 MJ/kg).

Part of the waste paper waste can be recycled and used as raw material in paper industry and in this case the weight of the waste paper attainable for energy recovery can be lower.

The obtained results indicated that much more than 150000 tons of hard coal can be replaced by the processed combustible wastes. A few years ago average RDF production costs in Western Europe attained the level of 15-20 $€$ per ton ${ }^{2}$. It means that depending on the waste processing line and hard coal the costs of the energy gen- 
Table 7. A calculation of hard coal weight that can be replaced by combustible waste

\begin{tabular}{|l|c|c|c|}
\hline Waste name & $\begin{array}{c}\text { Waste weight } \\
\text { registered at } \\
\text { Lower Silesia } \\
\text { (tons per year) }\end{array}$ & $\begin{array}{c}\text { Approx. } \\
\text { calorific value, } \\
\text { MJ/kg }\end{array}$ & $\begin{array}{c}\text { Quantity of } \\
\text { hard coal } \\
\text { (tons) }\end{array}$ \\
\hline Plastics & 18900 & 40 & 31500 \\
\hline Textiles & 1280 & 18.5 & 9870 \\
\hline Rubber & 3430 & 38 & 5430 \\
\hline Waste wood & 36400 & 18 & 27300 \\
\hline Waste paper & 91900 & 15 & 57437 \\
\hline Mixed wastes & 24000 & 22 & 22000 \\
\hline Total & ca 176000 & & 153537 \\
\hline
\end{tabular}

erated from combustible wastes can be two or three times lower in comparison to that from fossil fuels. Additionally, it is necessary to take into account the environmental advantages resulting from the limitation of emission and waste landfilling. On the other hand, we did not consider a large quantity of combustible municipal wastes, which can be also used in the alternative fuel production process. In this case the attainable weight of combustible wastes should be considerably higher.

\section{CONCLUSIONS}

It was shown that ca 175000 tons of combustible wastes was generated and registered in the area of Lower Silesia in 2005. The calorific value of these fuels changed in the range 15 and $40 \mathrm{MJ} / \mathrm{kg}$. As a rule the studied combustible wastes contained a small quantity of sulfur (except rubber and scrap tires) and chlorine (except waste paper). The main mineral impurities of the wastes were quite neutral components, mainly silica, alumina as well as iron and calcium oxides. The production of alternative fuels using municipal combustibles is a complicated process and needs numerous, up to ten, operations. The more uniform industrial wastes need a simpler production line. In this case only shredders, mills and sometimes sieves as well as the pelletizing or densifying apparatuses, can be successfully applied.

The main problem in the application of the milled fluffy wastes in the co-combustion with fossil fuels is a considerable difference in the density and separation of both types of fuels. In this case, in order to obtain heavier wastes grains giving more stable mixture with fossil fuels, an application of the densifying operation is necessary.

It was shown that the proper selection and processing of combustible wastes from the Lower Silesia area can deliver alternative fuels replacing more than 150000 tons of hard coal per year.

\section{LITERATURE CITED}

(1) Alter H.: International Reports The „Recycling” of Densified Refuse-Derived Fuels, Waste Management and Res., 1997 15, 13.

(2) Caputo A. C., Pelagagge M.: RDF production plants: I Economics and profitability, Appl. Thermal Eng., 2002, 22, 423.

(3) Caputo C., Pelagagge M.: RDF production plants: II Economics and profitability, Appl. Thermal Eng., 2002, 22, 439.

(4) Instruction of Economy Ministry dated March 21, 2002 regarding requirements connected with thermal wastes conversion (Dz. U. Nr 37 pos. 339 and $2004 \mathrm{Nr}$ 1, pos. 2). (Rozporządzenie Ministra Gospodarki z dnia 21.03.2002 r. w sprawie wymagań dotyczących prowadzenie procesu termicznego przekształcania odpadów).

(5) Instruction of Environment Ministry dated August 04, 2003. regarding emission standards from energetic plants (Dz. U. Nr 163 pos. 1584). (Rozporzadzenie Ministra Środowiska $\mathrm{z}$ dnia 04.08 .2003 r. w sprawie standardów emisyjnych $z$ instalacji).

(6) Instruction of Environment Ministry dated December 23, 2004 regarding the basic requirements in the field of emission and process parameters, (Dz. U. Nr 283, pos. 2842). (Rozporządzenie Ministra Środowiska z dnia 23.12.2004 r. w sprawie wymagań w zakresie wielkości emisji).

(7) Klein D. H., Andern A. W., Carter J. A., Emery J. F., Feldman C., Fulkerson W., Lyon W. S., Ogle J. C., Talmi Y., Van Hook R. I., Boston N.: Environ. Sci, Technol., 1975, 9, 973.

(8) Larjava K.: „On the Measurements of Volatile Metal Species at Elevated Temperature", Publication 137, Technical Research Centre of Finland, Espoo, Finland, 1993.

(9) Greenberg R. R., Zoller W. H., Gordon G. E.: Environ. Sci. Technol., 1978, 12, 566. 